\title{
Nitrogen Uptake and Mobilization by Hydrangea Leaves from Foliar-sprayed Urea in Fall Depend on Plant Nitrogen Status
}

\author{
Guihong $\mathbf{B i}^{1}$ \\ Truck Crops Branch Experiment Station, Mississippi State University, 2024 \\ Experiment Station Road, P.O. Box 231, Crystal Springs, MS 39059
}

\section{Carolyn F. Scagel}

U.S. Department of Agriculture, Agricultural Research Service, Horticultural Crops Research Unit, 3420 NW Orchard Avenue, Corvallis, OR 97330

\author{
Additional index words. Hydrangea macrophylla 'Berlin', ${ }^{15} \mathrm{~N}$
}

\begin{abstract}
Rooted liners of Hydrangea macrophylla (Thunb.) Ser. 'Berlin' were fertigated with different rates of nitrogen (N) from July to Sept. 2007 and leaves were sprayed with ${ }^{15} \mathrm{~N}$-labeled urea in late October to evaluate urea uptake and ${ }^{15} \mathrm{~N}$ translocation by hydrangea leaves in relation to plant $\mathbf{N}$ status. Four plants from each $\mathbf{N}$ fertigation rate were harvested before they were sprayed with urea and $2,5,10$, and 15 days after urea spray. Increasing rate of $\mathbf{N}$ fertigation increased plant $\mathrm{N}$ content in October before being sprayed with urea. Leaves rapidly absorbed ${ }^{15} \mathrm{~N}$ from urea spray. The highest rate of ${ }^{15} \mathrm{~N}$ uptake occurred during the first 2 days after urea spray and then decreased. Export of ${ }^{15} \mathrm{~N}$ from leaves occurred rapidly after uptake and the highest rate of ${ }^{15} \mathrm{~N}$ export occurred during the first 2 days after urea spray and then decreased. During the first 5 days after urea spray, the rate of ${ }^{15} \mathrm{~N}$ uptake by leaves and export from leaves decreased with increasing rate of $\mathrm{N}$ fertigation. On a whole plant basis, the total amount of ${ }^{15} \mathrm{~N}$ from foliar ${ }^{15} \mathrm{~N}$-urea spray increased with increasing rate of $\mathrm{N}$ fertigation; however, the percentage of ${ }^{15} \mathrm{~N}$ exported from leaves and the percentage of $\mathrm{N}$ that derived from foliar ${ }^{15} \mathrm{~N}$-urea spray decreased with increasing rate of $\mathrm{N}$ fertigation. Results suggest that hydrangea plants with lower $N$ status in the fall are more efficient in absorbing and translocating $\mathbf{N}$ from foliar urea than plants with higher $\mathbf{N}$ status.
\end{abstract}

Perennial plants can store nitrogen $(\mathrm{N})$ and remobilize the stored $\mathrm{N}$ for new growth the next spring (Millard, 1995). There is a positive correlation between the amount of stored $\mathrm{N}$ in perennial plant tissues and plant growth in early spring (Cheng et al., 2001). The amount of stored $\mathrm{N}$ available for plant growth in spring can be enhanced by $\mathrm{N}$ fertilization during the previous growing season, and uptake of $\mathrm{N}$ late in the season contributes more to storage than does $\mathrm{N}$ taken up earlier in the season (Sanchez et al., 1991; Tagliavini et al., 1999; Weinbaum et al., 1984). However, generous $\mathrm{N}$ applications to the soil late in the season can cause continued

\footnotetext{
Received for publication 3 July 2008. Accepted for publication 13 Aug. 2008.

Contribution of the Mississippi Agricultural and Forestry Experiment Station Journal article no. J-11392.

We thank Mark Terkanian, Keri L. Paridon, Peter Hudson, and Melvin Townsend for technical assistance.

Mention of a trademark, proprietary product, or vendor does not constitute a guarantee or warranty of the product by the U.S. Dept. of Agriculture and does not imply its approval to the exclusion of other products or vendors that also may be suitable.

${ }^{1}$ To whom reprint requests should be addressed; e-mailgb250@msstate.edu
}

occurrence of diseases (Bailey, 1989). However, early defoliation can significantly decrease the amount of $\mathrm{N}$ stored in plants and potentially result in poor growth or plant performance the next growing season (Cheng and Fuchigami, 2002; Guak et al., 2001). With woody perennial plants, fall sprays with urea can increase the level of storage $\mathrm{N}$ compounds such as amino acids and proteins (Dong et al., 2002) and decrease the negative effects of early defoliation (manual or chemical) on tree growth the next spring (Guak et al., 2001); however, the magnitude of the urea effect varies depending on plant species and timing of urea sprays (Bi et al., 2005; Guak et al., 2001; Johnson et al., 2001). Spraying hydrangea leaves with urea before defoliation can improve plant performance during forcing (growth, number of flowers, and flower size) (Bi et al., 2008). Although the influence of urea sprays on hydrangea performance has been documented, knowledge of how rapidly the urea $\mathrm{N}$ is taken up and mobilized within plants is not known. This information is important for synchronizing the timing of foliar sprays in relation to defoliation treatments. A better understanding of factors that influence $\mathrm{N}$ uptake and mobilization after urea sprays is needed to optimize plant culture during the growing season and determine the timing of urea sprays before manual or chemical defoliation in fall

Using 'Berlin' hydrangea, the objectives of this study were to determine: 1 ) whether $\mathrm{N}$ uptake and mobilization of $\mathrm{N}$ from urea sprays depends on the $\mathrm{N}$ status of the plant in fall; and 2) the duration of $\mathrm{N}$ uptake and translocation from urea sprays.

\section{Materials and Methods}

growth and delay dormancy and cold acclimation (Bramlage et al., 1980; Millard, 1995; Tagliavini et al., 1999). Foliar fertilization in fall is an alternative to supplying $\mathrm{N}$ to the soil. In some perennial plant species, foliar sprays of urea after terminal bud set can improve $\mathrm{N}$ storage without stimulating new growth or delaying dormancy (Cheng and Fuchigami, 2002; Sanchez et al., 1990).

Urea is commonly used for foliar fertilizer applications because it is nonpolar, highly soluble in water, and can be rapidly and efficiently absorbed by leaves (Bondada et al., 2001; Dong et al., 2002). Several studies have shown leaves rapidly absorb a majority of the urea from foliar spray applications in fall, even during leaf senescence, and translocate the absorbed $\mathrm{N}$ from the leaves into storage tissues (Dong et al., 2002; Klein and Weinbaum, 1985; Rosecrance et al., 1998; Shim et al., 1972). However, with woody perennial plants, responses to foliar urea sprays are affected by plant $\mathrm{N}$ status. For example, spraying leaves on apple trees with urea in fall was more effective in increasing $\mathrm{N}$ reserves for plants with low $\mathrm{N}$ status than for those with high N status (Cheng et al., 2002).

In the production of florists' hydrangea, manual or chemical defoliation before cold storage is recommended to help prevent the
Plant material, nitrogen treatments, and sampling. Rooted liners of Hydrangea macrophylla (Thunb.) Ser. 'Berlin', a cultivar in the CITYLINE series, were potted into Elite/ Ultra Azalea containers $(17.8 \mathrm{~cm}$ diameter, $12.7 \mathrm{~cm}$ high; ITML Horticultural Products Inc., Brantford, Ontario, Canada) containing a 5:4:1 (by volume) mix of pine bark, peatmoss, and sand on 20 June 2007. Each pot contained one plant. Plants were grown outdoors under shadecloth (40\% shade) in Crystal Springs, MS (lat. 31 $59^{\prime} \mathrm{N}$, long. $90^{\circ} 21^{\prime} \mathrm{W}$ ) and supplied with $14 \mathrm{~mm} \mathrm{~N}$ using $20 \mathrm{~N}-4.4 \mathrm{P}$ 16.6K fertilizer (TotalGro 20-10-20; SDT Industries, Inc., Winnsboro, LA) once per week for 2 weeks. On 10 July 2007, 20 uniform plants were randomly assigned to one of five groups, and plants in each group were supplied manually with $400 \mathrm{~mL}$ of a modified Hoagland's solution (Hoagland and Arnon, 1950) containing one of five $\mathrm{N}$ concentrations $(0,5,10,15$, or $20 \mathrm{~mm} \mathrm{~N}$ from $\mathrm{NH}_{4} \mathrm{NO}_{3}$ ) two times per week for 10 weeks (20 plants per $\mathrm{N}$ treatment $=100$ plants total $)$. Plants were drip-irrigated with groundwater as needed throughout the growing season with no additional water supplied on the day of fertigation.

Plant foliage was sprayed to the point of runoff with $3 \%$ urea (enriched to 10 atom 
percent with ${ }^{15} \mathrm{~N}$ ) using a backpack sprayer on 25 Oct. 2007 (U treatment). Before spraying plants, the surface of the growing substrate was covered with plastic to avoid urea dripping onto the substrate. Four plants from each $\mathrm{N}$ fertigation treatment were harvested before $U$ treatment and 2, 5, 10, and $15 \mathrm{~d}$ after $\mathrm{U}$ treatment. At each harvest, plants were destructively sampled and divided into leaves, stems, and roots. Total leaf area $\left(\mathrm{cm}^{2}\right)$ of each plant was measured using a LI-COR Model LI-3100C Area Meter (LICOR Environmental, Lincoln, NE). Leaves and stems were washed in $0.1 \mathrm{~mol} \cdot \mathrm{m}^{-3} \mathrm{HCL}$ for 2 to $3 \mathrm{~min}$ and then rinsed with doubledistilled water $\left(\mathrm{ddH}_{2} \mathrm{O}\right)$ to remove any urea residue. The roots were washed only with $\mathrm{ddH}_{2} \mathrm{O}$. All tissue samples were dried in a $60{ }^{\circ} \mathrm{C}$ forced-air oven, weighed, and then ground with a Wiley mill (40-mesh; Thomas Scientific, Swedesboro, NJ).

Nitrogen and ${ }^{15} \mathrm{~N}$ measurement and calculations. Concentration of $\mathrm{N}$ and ${ }^{15} \mathrm{~N}$ in samples were determined with a Europa Scientific Corporation Roboprep $\mathrm{C} / \mathrm{N}$ analyzer coupled to a Tracermass Mass Spectrometer (Europa Scientific Ltd., Crewe, U.K.) at the Stable Isotope Research Unit at Oregon State University in Corvallis, OR. The percentage of $\mathrm{N}$ derived from urea fertilizer (NDFF; \%) in each tissue was calculated as described by Khemira et al. (1998) using a natural atom percent ${ }^{15} \mathrm{~N}$ abundance value of $0.3663 \%$ : (tissue atom $\%{ }^{15} \mathrm{~N}-0.3663$ ) $\times 100 \% /\left(\right.$ fertilizer atom $\left.\%{ }^{15} \mathrm{~N}-0.3663\right)$.

The total $\mathrm{N}$ content of each plant tissue (roots, stems, leaves) was calculated by multiplying the $\mathrm{N}$ concentration in each tissue by the dry weight of the tissue. Total $\mathrm{N}$ content in each plant was calculated as the sum of $\mathrm{N}$ content in each tissue. The ${ }^{15} \mathrm{~N}$ content of each plant tissue was calculated by multiplying the NDFF in each tissue by the total $\mathrm{N}$ content of the tissue. Total ${ }^{15} \mathrm{~N}$ content in each plant was calculated as the sum of ${ }^{15} \mathrm{~N}$ content in each tissue. The rate of ${ }^{15} \mathrm{~N}$ uptake at each harvest was calculated as the difference between ${ }^{15} \mathrm{~N}$ content per plant at each harvest and mean ${ }^{15} \mathrm{~N}$ content per plant at the previous harvest divided by total leaf area and days between the two harvests $\left(\mathrm{g} \cdot \mathrm{m}^{-2} \cdot \mathrm{d}^{-1}\right)$. The rate of ${ }^{15} \mathrm{~N}$ export from leaves was calculated as the difference between ${ }^{15} \mathrm{~N}$ content in stems and roots per plant at each harvest and mean ${ }^{15} \mathrm{~N}$ content in stems and roots per plant at the previous harvest divided by total leaf area and days between the two harvests $\left(\mathrm{g} \cdot \mathrm{m}^{-2} \cdot \mathrm{d}^{-1}\right)$. On a whole plant basis, plant NDFF was calculated as total plant ${ }^{15} \mathrm{~N}$ content divided by total plant $\mathrm{N}$ content. The percentage of ${ }^{15} \mathrm{~N}$ exported from leaves was calculated as the sum of ${ }^{15} \mathrm{~N}$ content in stems and roots divided by total ${ }^{15} \mathrm{~N}$ content in the plant.

Experimental design and statistical analyses. The experiment was a completely randomized design with each experimental unit (container) replicated four times for each $\mathrm{N}$ fertigation treatment $(0,5,10,15,20 \mathrm{~mm}$ $\mathrm{N})$ and harvest date $(0,2,5,10,15 \mathrm{~d}$ after urea spray). Data were analyzed in a complete factorial design using analysis of variance
(ANOVA) with $\mathrm{N}$ treatment and harvest date as main effects. Where indicated by ANOVA, means were separated using Tukey's honestly significant difference at $P=0.05$. Means of interactions are only presented when indicated as significant $(P<0.05)$ by ANOVA. Plant response to $\mathrm{N}$ fertigation treatment was evaluated using linear and quadratic polynomial contrasts based on the $\mathrm{N}$ fertigation rates in 2007. All analyses were performed using Statistica (Statsoft, Inc., Tulsa, OK).

\section{Results}

Effects of nitrogen fertigation rate on plant nitrogen content in fall. Increasing rate of $\mathrm{N}$ fertigation increased total plant $\mathrm{N}$ content (Table 1). Plants grown at the highest $\mathrm{N}$ fertigation rate contained $\approx 741 \mathrm{mg}$ more $\mathrm{N}$ than plants grown at the lowest $\mathrm{N}$ fertigation rate. Increasing $\mathrm{N}$ fertigation rate increased the $\mathrm{N}$ concentrations in all plant structures (leaves, stems, and roots).

Urea ${ }^{15} \mathrm{~N}$ uptake in relation to plant nitrogen content. Leaves rapidly absorbed
${ }^{15} \mathrm{~N}$ from urea after they were sprayed with urea. The highest rate of ${ }^{15} \mathrm{~N}$ uptake occurred during the first $2 \mathrm{~d}$ after urea sprays and then decreased (Fig. 1A). No significant ${ }^{15} \mathrm{~N}$ uptake occurred after $5 \mathrm{~d}$ following urea spray. Uptake rate of ${ }^{15} \mathrm{~N}$ from urea during the first

Table 1. Influence of nitrogen $(\mathrm{N})$ fertigation rate in 2007 on N concentrations of leaves, stems, and roots and total plant $\mathrm{N}$ content of Hydrangea macrophylla 'Berlin' in Oct. 2007.

\begin{tabular}{|c|c|c|c|c|}
\hline \multirow{2}{*}{$\begin{array}{l}\mathrm{N} \text { treatment } \\
(\mathrm{mm})^{\mathrm{z}}\end{array}$} & \multicolumn{3}{|c|}{$\mathrm{N}$ concn $(\%)$} & \multirow{2}{*}{$\begin{array}{c}\text { Total } \\
\text { plant } N \\
\text { content } \\
(\mathrm{mg})\end{array}$} \\
\hline & Leaf & Stem & Root & \\
\hline 0 & $0.93 \mathrm{~d}^{\mathrm{y}}$ & $0.80 \mathrm{~b}$ & $1.06 \mathrm{c}$ & 54.6 \\
\hline 5 & $1.24 \mathrm{c}$ & $0.96 \mathrm{ab}$ & $1.23 \mathrm{bc}$ & 198.5 \\
\hline 10 & $1.65 \mathrm{~b}$ & $1.07 \mathrm{ab}$ & $1.33 \mathrm{~b}$ & 482.6 \\
\hline 15 & $1.83 \mathrm{ab}$ & $1.15 \mathrm{a}$ & $1.43 \mathrm{~b}$ & 687.3 \\
\hline 20 & $2.04 \mathrm{a}$ & $1.16 \mathrm{a}$ & $1.72 \mathrm{a}$ & 795.8 \\
\hline
\end{tabular}

${ }^{2} \mathrm{~N}=$ rate of $\mathrm{N}$ fertigation in $2007(0,5,10,15$, and $20 \mathrm{~mm} \mathrm{~N}$ from $\mathrm{NH}_{4} \mathrm{NO}_{3}$ ).

${ }^{\mathrm{y}}$ Means within a column followed by different letters are significantly different (Tukey's honestly significant difference test at $P=0.05 ; \mathrm{n}=4$ ).

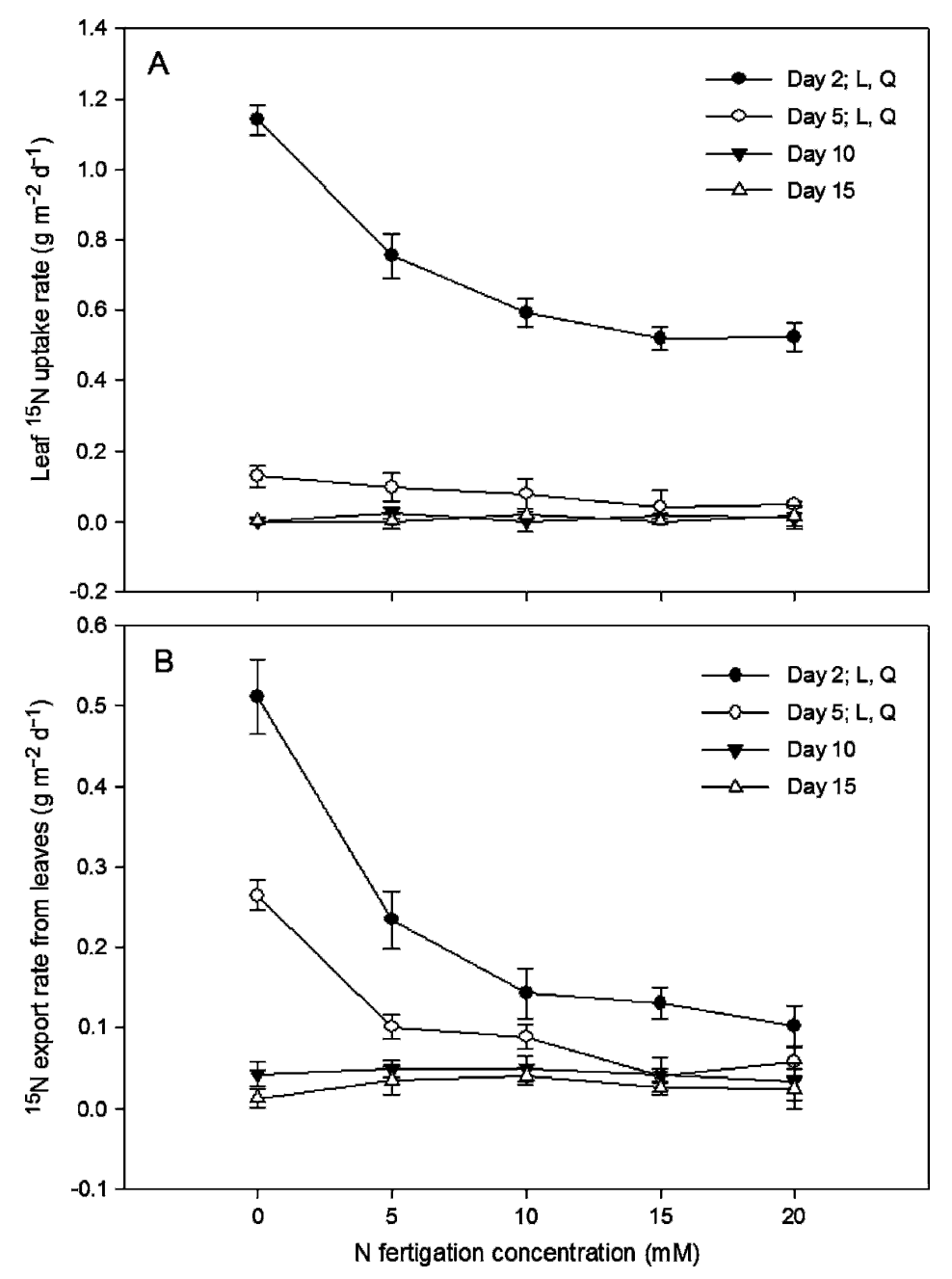

Fig. 1. Uptake rate (A) and export rate $(\mathbf{B})$ of ${ }^{15} \mathrm{~N}$-labeled nitrogen $(\mathrm{N})$ from urea by leaves of Hydrangea macrophylla 'Berlin' grown with one of five rates of $\mathrm{N}$ fertigation $(0,5,10,15$, or $20 \mathrm{~mm} \mathrm{~N}$ from $\mathrm{NH}_{4} \mathrm{NO}_{3}$ ) from July to Sept. 2007 and sprayed with urea in Oct. 2007. Plants were harvested before being sprayed with urea and 2, 5, 10, and $15 \mathrm{~d}$ after sprays. Day $2=$ uptake $(\mathbf{A})$ or export (B) rate in first $2 \mathrm{~d}$ after sprays; Day $5=$ uptake $(\mathbf{A})$ or export $(\mathbf{B})$ rate between $2 \mathrm{~d}$ and $5 \mathrm{~d}$ after sprays; Day $10=$ uptake (A) or export (B) rate between $5 \mathrm{~d}$ and $10 \mathrm{~d}$ after sprays; Day $15=$ uptake (A) or export (B) rate between $10 \mathrm{~d}$ and $15 \mathrm{~d}$ after sprays. Error bars on data points represent SES $(\mathrm{n}=4)$. Significant $(P<0.05)$ linear $(\mathrm{L})$ and quadratic $(\mathrm{Q})$ contrasts across $\mathrm{N}$ fertigation rates denoted in legend. 
$2 \mathrm{~d}$ after spraying decreased with increasing $\mathrm{N}$ fertigation rate and plants in the 0 and $5 \mathrm{~mm}$ $\mathrm{N}$ treatments took up more ${ }^{15} \mathrm{~N}$ per unit leaf area than plants fertigated at rates of $10 \mathrm{~mm} \mathrm{~N}$ and above. Uptake of ${ }^{15} \mathrm{~N}$ between $2 \mathrm{~d}$ and $5 \mathrm{~d}$ after spraying decreased with increasing $\mathrm{N}$ rate and plants in the $0 \mathrm{~mm} \mathrm{~N}$ treatment took up more ${ }^{15} \mathrm{~N}$ per unit leaf area than plants fertigated at the 15 and $20 \mathrm{~mm} \mathrm{~N}$ rate. By day 15 , plants with the lowest $\mathrm{N}$ content absorbed $\approx 1.06$ times more ${ }^{15} \mathrm{~N}$ on a unit leaf area basis than those with the highest $\mathrm{N}$ content.

Urea $-{ }^{15} \mathrm{~N}$ export in relation to plant nitrogen content. Export of ${ }^{15} \mathrm{~N}$ from leaves occurred rapidly after urea spray (Fig. 1B). The highest rates of ${ }^{15} \mathrm{~N}$ export occurred during the first $2 \mathrm{~d}$ after urea sprays and then decreased. Export rate of ${ }^{15} \mathrm{~N}$ from leaves during the first $2 \mathrm{~d}$ after spraying decreased with increasing $\mathrm{N}$ fertigation rate and plants in the 0 and $5 \mathrm{~mm} \mathrm{~N}$ treatments exported more ${ }^{15} \mathrm{~N}$ per unit leaf area than plants fertigated at $10 \mathrm{~mm}$ and above. Export rate of ${ }^{15} \mathrm{~N}$ from leaves between $2 \mathrm{~d}$ and $5 \mathrm{~d}$ after spraying decreased with increasing $\mathrm{N}$ rate and plants in the $0 \mathrm{~mm} \mathrm{~N}$ treatment exported more ${ }^{15} \mathrm{~N}$ per unit leaf area than plants fertigated at $5 \mathrm{~mm}$ and above. There was no significant difference in ${ }^{15} \mathrm{~N}$ export rate from leaves among plants in the different $\mathrm{N}$ treatments after $5 \mathrm{~d}$ following urea spray. By day 15, plants with the lowest $\mathrm{N}$ content exported $\approx 2.21$ times more ${ }^{15} \mathrm{~N}$ from leaves on a unit leaf area basis than those with the highest $\mathrm{N}$ content.

Approximately $77 \%$ of the absorbed ${ }^{15} \mathrm{~N}$ in plants with the lowest $\mathrm{N}$ content was exported from the leaves to stems and roots $15 \mathrm{~d}$ after plants were sprayed with urea (Fig. 2A). This proportion decreased with increasing plant $\mathrm{N}$ content, reaching $50 \%$ in plants with the highest $\mathrm{N}$ content.

On a whole plant basis, the total amount of ${ }^{15} \mathrm{~N}$ in plants derived from foliar ${ }^{15} \mathrm{~N}$-urea sprays increased with increasing $\mathrm{N}$ fertigation rate $15 \mathrm{~d}$ after plants were sprayed with urea and plants fertigated at $10 \mathrm{~mm}$ and below had less ${ }^{15} \mathrm{~N}$ than plants fertigated at 15 and $20 \mathrm{~mm} \mathrm{~N}$ (Fig. 2B); however, the proportion of ${ }^{15} \mathrm{~N}$-derived from the foliar applied urea decreased with increasing $\mathrm{N}$ fertigation rate (Fig. 2C). The NDFF accounted for $\approx 38 \%$ of the total $\mathrm{N}$ pool in plants with the lowest $\mathrm{N}$ content and then decreased to $31 \%$ in plants with the highest $\mathrm{N}$ content.

\section{Discussion}

Hydrangea leaves rapidly absorb $\mathrm{N}$ from urea after being sprayed in fall. This is consistent with results obtained from other studies using woody plants. Nectarine trees can take up from $58 \%$ to $69 \%$ of the $\mathrm{N}$ from foliar sprayed urea during the 3- to 7-d period after spraying (Tagliavini et al., 1998). Up to $75 \%$ of applied urea was absorbed over a 24-h period by apple leaves (Shim et al., 1973). Approximately $60 \%$ to $70 \%$ of applied urea can be absorbed by olive leaves within $24 \mathrm{~h}$ (Klein and Weinbaum, 1984).

There was no significant $\mathrm{N}$ uptake by hydrangea leaves after $5 \mathrm{~d}$ following urea
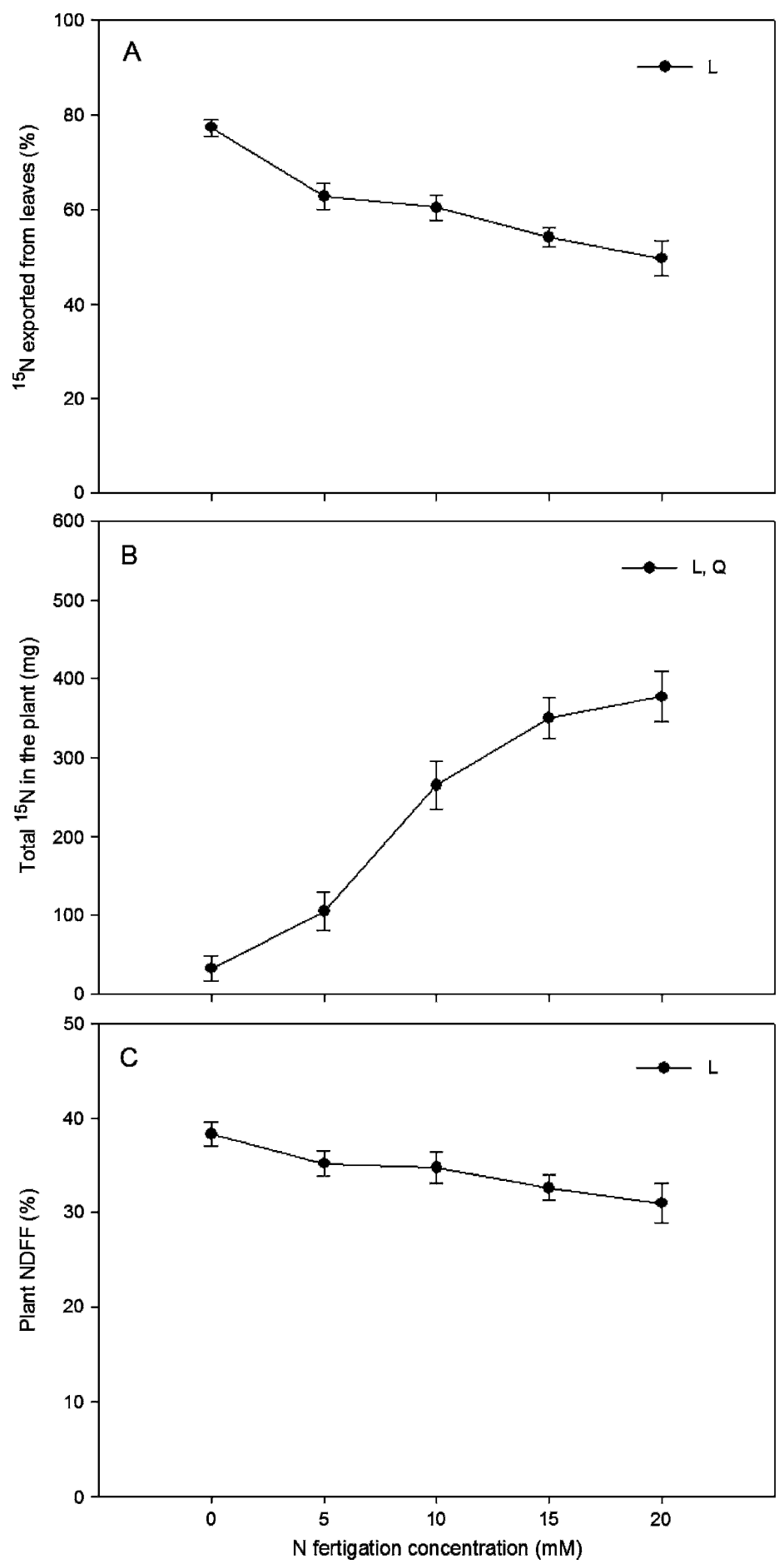

Fig. 2. Percentage of ${ }^{15} \mathrm{~N}$ exported from leaves (A), plant total ${ }^{15} \mathrm{~N}$ content $(\mathbf{B})$, and plant NDFF (C) of Hydrangea macrophylla 'Berlin' grown with one of five rates of nitrogen $(\mathrm{N})$ fertigation $(0,5,10,15$, or $20 \mathrm{~mm} \mathrm{~N}$ from $\mathrm{NH}_{4} \mathrm{NO}_{3}$ ) from July to Sept. 2007 and sprayed with urea in Oct. 2007. Data were taken $15 \mathrm{~d}$ after urea spray. NDFF $=$ the percentage of $\mathrm{N}$ derived from urea fertilizer. Error bars on data points represent SES $(n=4)$. Significant $(P<0.05)$ linear $(L)$ and quadratic $(Q)$ contrasts across $N$ fertigation rates denoted in legend.

sprays suggesting after this time, urea was either unavailable for uptake or leaves were no longer able to absorb urea-N. Plants were drip-irrigated during this study and rain was prevented from dropping onto the plants during the $15 \mathrm{~d}$ after spraying; therefore, urea was probably not washed off the leaves. Others (Bondada et al., 2001; Kissel and Cabrera, 1988) have reported that $\mathrm{N}$ can be lost from urea sprayed onto leaves by evaporation, volatilization, or both. Spraying leaves with urea may cause some phytotoxicity to plants (Krogmeier et al., 1989). Damage to leaves of perennial plants in fall when manual or chemical defoliation is used as a common production practice may not be important to the esthetic quality of the future crop; however, it is possible that leaves may become less capable of absorbing urea-N if leaf cells are damaged by sprays. 
Hydrangea leaves exported most of the $\mathrm{N}$ from urea sprays in the first $2 \mathrm{~d}$ after sprays. This timeframe of $\mathrm{N}$ export is similar to export from leaves of young potted apple trees in which most $\mathrm{N}$ uptake and export from urea sprays occurred during the first $2 \mathrm{~d}$ after sprays (Dong et al., 2002). A study with peach trees showed that most of the absorbed $\mathrm{N}$ from urea spray in fall was quickly transported out of the leaves during the first week after urea spray (Johnson et al., 2001).

Increasing rate of $\mathrm{N}$ fertigation increased total plant $\mathrm{N}$ content. This is consistent with results obtained on some other plant species (Bi et al., 2007; Cheng et al., 2001). An inverse relationship between plant $\mathrm{N}$ content and the likelihood of response to foliar urea applications has been suggested (Weinbaum, 1988). Mature apple trees with a high N content show no response to postharvest foliar applications of urea (Delap, 1967). The response of pear trees to postharvest foliar sprays of urea was also related to tree $\mathrm{N}$ status (Sanchez et al., 1990). In apple nursery trees, foliar urea sprays after terminal bud set can increase the amount of stored $\mathrm{N}$; however, trees with low $\mathrm{N}$ status were more efficient in absorbing and translocating $\mathrm{N}$ from foliar urea applications than those with higher $\mathrm{N}$ status (Cheng et al., 2002). Our data indicated that hydrangea with lower $\mathrm{N}$ content can absorb and export more ${ }^{15} \mathrm{~N}$ on a unit leaf area basis than those with higher $\mathrm{N}$ status.

Greater efficiency in urea-N uptake and export was most obvious during the first $5 \mathrm{~d}$ after spraying. Interestingly, efficiency in urea-N uptake and export was similar in plants in the $10 \mathrm{~mm}, 15 \mathrm{~mm}$, and $20 \mathrm{~mm} \mathrm{~N}$ treatments, although initial $\mathrm{N}$ content of plants in these treatments were significantly different. This suggests plants with lower $\mathrm{N}$ content from $\mathrm{N}$ fertigation treatments may benefit even more from additional urea sprays $5 \mathrm{~d}$ after the initial urea spray treatment. These data also suggest there may be some threshold $\mathrm{N}$ content above which plant response to urea sprays is similar, regardless of $\mathrm{N}$ content.

In our study, hydrangea leaves exported between $50 \%$ and $77 \%$ of the absorbed $\mathrm{N}$ $15 \mathrm{~d}$ after sprays depending on plant $\mathrm{N}$ content from $\mathrm{N}$ fertigation treatments. With young apple trees, $\approx 64 \%$ of absorbed $\mathrm{N}$ was exported from leaves $20 \mathrm{~d}$ after sprays (Dong et al., 2002). Cheng et al. (2002) reported $\approx 80 \%$ to $90 \%$ of the urea-N absorbed from foliar sprays is mobilized back into storage tissues of young apple trees at the end of natural leaf fall. Between $54 \%$ and $60 \%$ of the urea-N absorbed by the canopy of potted nectarine trees was recovered in storage during leaf senescence (Tagliavini et al., 1998). The high variation in export reported in studies may be a result of differences in plant metabolism between species in fall, the age or developmental stage of plants when harvested, the number or rate of urea spray used, the timing of urea sprays, plant nutrient status, and weather conditions. For example, in Mississippi, natural defoliation of hydrangeas generally occurs during November and December. Our results with 'Berlin' hydran- gea suggest when plants in Mississippi are sprayed in late October, urea-N is not only exported to storage in physiologically active plants but may also be retained in the leaves to support leaf metabolism until closer to the time of natural defoliation.

In conclusion, there was little uptake or mobilization of urea-N $5 \mathrm{~d}$ after spraying. This suggests that when growing hydrangea in Mississippi, overhead irrigation will have little influence on the uptake of $\mathrm{N}$ from urea sprays $5 \mathrm{~d}$ after spraying. Additionally, defoliation practices commonly used with florists' hydrangea will have little influence on mobilization of $\mathrm{N}$ from urea after this time. Therefore, florists' hydrangea can be defoliated $\approx 1$ week after plants are sprayed with urea without negatively affecting urea-N uptake or mobilization. More research is needed to evaluate the optimum rates and times (frequency) of urea sprays, possible effects of spraying urea in combination with chemical defoliants, and cultivar variation in response to urea sprays.

\section{Literature Cited}

Bailey, D.A. 1989. Hydrangea production. Timber Press, Portland, OR.

Bi, G., C.F. Scagel, L. Cheng, and L.H. Fuchigami. 2005. Effects of copper, zinc and urea on defoliation and nitrogen reserves in nursery plants of almond. J. Hort. Sci. Biotechnol. 80: 746-750.

Bi, G., C.F. Scagel, L.H. Fuchigami, and R.P. Regan. 2007. Rate of nitrogen application during the growing season alters the response of container-grown rhododendron and azalea to foliar application of urea in the autumn. J. Hort. Sci. Biotechnol. 82:753-763.

Bi, G., C.F. Scagel, and R. Harkess. 2008. Rate of nitrogen fertigation during vegetative growth and spray applications of urea in the autumn alters growth and flowering of florists' hydrangeas. HortScience 43:472-477.

Bondada, B.R., J.P. Syvertsen, and L.G. Albrigo. 2001. Urea nitrogen uptake by citrus leaves. HortScience 36:1061-1065.

Bramlage, W.J., M. Drake, and W.J. Lord. 1980 The influence of mineral nutrition on the quality and storage performance of pome fruits grown in North America, p. 29-39. In: Atkinson, D., J.E. Jackson, R.O. Sharples, and W.N. Waller (eds.). Mineral nutrition of fruit trees. Butterworths, London, U.K.

Cheng, L., S. Dong, and L.H. Fuchigami. 2002. Urea uptake and nitrogen mobilization by apple leaves in relation to tree nitrogen status in autumn. J. Hort. Sci. Biotechnol. 77:13-18.

Cheng, L., S. Dong, S. Guak, and L.H. Fuchigami. 2001. Effects of nitrogen fertigation on reserve nitrogen and carbohydrate status and regrowth performance of pear nursery plants. Acta Hort. 564:51-62.

Cheng, L. and L.H. Fuchigami. 2002. Growth of young apple trees in relation to reserve nitrogen and carbohydrates. Tree Physiol. 22:1297-1303.

Delap, A.V. 1967. The responses of young apple trees of differing nitrogen status to a urea spray in autumn. Annual Report of the East Malling Research Station for 1966:139-143.

Dong, S., L. Cheng, C.F. Scagel, and L.H. Fuchigami. 2002. Nitrogen absorption, translocation and distribution from urea applied in autumn to leaves of young potted apple
(Malus domestica) trees. Tree Physiol. 22: 1305-1310.

Guak, S., L. Cheng, and L.H. Fuchigami. 2001. Foliar urea pretreatment tempers inefficient $\mathrm{N}$ recovery resulting from copper chelate (CuEDTA) defoliation of apple nursery plants. J. Hort. Sci. Biotechnol. 76:35-39.

Hoagland, D.R. and D.I. Arnon. 1950. The waterculture method for growing plants without soil. Calif. Agr. Expt. Sta. Circ. 347.

Johnson, R.S., R. Rosecrance, S. Weinbaum, H. Andris, and J. Wang. 2001. Can we approach complete dependence on foliar-applied urea nitrogen in an early-maturing peach? J. Amer. Soc. Hort. Sci. 126:364-370.

Khemira, H., T.L. Righetti, and A.N. Azarenko. 1998. Nitrogen partitioning in apple as affected by timing and tree growth habit. J. Hort. Sci. 73:217-223.

Kissel, D.E. and M.L. Cabrera. 1988. Ammonia volatilization from urea and an experimental thiazine fertilizer. HortScience 23:1087.

Klein, I. and S.A. Weinbaum. 1984. Foliar application of urea to olive: Translocation of urea nitrogen as influenced by sink demand and nitrogen deficiency. J. Amer. Soc. Hort. Sci. 109:356-360.

Klein, I. and S.A. Weinbaum. 1985. Foliar application of urea to almond and olive: Leaf retention and kinetics of uptake. J. Plant Nutr. 8:117-129.

Krogmeier, M.J., G.W. McCarty, and J.M. Bremner. 1989. Phytotoxicity of foliar-applied urea. Proc. Natl. Acad. Sci. USA 86:8189-8191.

Millard, P. 1995. Internal cycling of nitrogen in trees. Acta Hort. 383:3-13.

Rosecrance, R.C., R.S. Johnson, and S.A. Weinbaum. 1998. The effect of timing of postharvest foliar urea sprays on nitrogen absorption and partitioning in peach and nectarine trees. J. Hort. Sci. Biotechnol. 73:856-861.

Sanchez, E.E., T.L. Righetti, D. Sugar, and P.B. Lombard. 1990. Response of 'Comice' pear trees to a postharvest urea spray. J. Hort. Sci. 65:541-546.

Sanchez, E.E., T.L. Righetti, D. Sugar, and P.B. Lombard. 1991. Recycling of nitrogen in fieldgrown 'Comice' pears. J. Hort. Sci. 66:479486.

Shim, K.K., J.S. Titus, and W.E. Splittstoesser. 1972. The utilization of post-harvest urea sprays by senescencing apple leaves. J. Amer. Soc. Hort. Sci. 97:592-596.

Shim, K.K., J.S. Titus, and W.E. Splittstoesser. 1973. The fate of carbon and nitrogen from urea applied to foliage of senescing apple trees. J. Amer. Soc. Hort. Sci. 98:360-366.

Tagliavini, M., P. Millard, and M. Quartieri. 1998. Storage of foliar absorbed nitrogen and remobilization for spring growth in young nectarine (Prunus persica var. nectarina) trees. Tree Physiol. 18:203-207.

Tagliavini, M., P. Millard, M. Quartieri, and B. Marangoni. 1999. Timing of nitrogen uptake affects winter storage and spring remobilisation of nitrogen in nectarine (Prunus persica var. nectarina) trees. Plant Soil 211:149-153.

Weinbaum, S.A. 1988. Foliar nutrition of fruit trees, p. 81-100. In: Neumann, P.E. (ed.). Plant growth and leaf-applied chemicals. CRC Press, Boca Raton, FL.

Weinbaum, S.A., I. Klein, F.E. Broadbent, W.C. Micke, and T.T. Muraoka. 1984. Effect of time of nitrogen application and soil texture on the availability of isotopically labeled fertilizer nitrogen to reproductive and vegetative growth of mature almond trees. J. Amer. Soc. Hort. Sci. 109:339-343. 